\title{
Project finance as a driver of economic growth in low- income countries
}

Citation for published version (APA):

Kleimeier, S., \& Versteeg, R. J. (2009). Project finance as a driver of economic growth in low-income countries. METEOR, Maastricht University School of Business and Economics. METEOR Research Memorandum No. 011 https://doi.org/10.26481/umamet.2009011

Document status and date:

Published: 01/01/2009

DOI:

10.26481/umamet.2009011

Document Version:

Publisher's PDF, also known as Version of record

\section{Please check the document version of this publication:}

- A submitted manuscript is the version of the article upon submission and before peer-review. There can be important differences between the submitted version and the official published version of record.

People interested in the research are advised to contact the author for the final version of the publication, or visit the DOI to the publisher's website.

- The final author version and the galley proof are versions of the publication after peer review.

- The final published version features the final layout of the paper including the volume, issue and page numbers.

Link to publication

\footnotetext{
General rights rights.

- You may freely distribute the URL identifying the publication in the public portal. please follow below link for the End User Agreement:

www.umlib.nl/taverne-license

Take down policy

If you believe that this document breaches copyright please contact us at:

repository@maastrichtuniversity.nl

providing details and we will investigate your claim.
}

Copyright and moral rights for the publications made accessible in the public portal are retained by the authors and/or other copyright owners and it is a condition of accessing publications that users recognise and abide by the legal requirements associated with these

- Users may download and print one copy of any publication from the public portal for the purpose of private study or research.

- You may not further distribute the material or use it for any profit-making activity or commercial gain

If the publication is distributed under the terms of Article $25 \mathrm{fa}$ of the Dutch Copyright Act, indicated by the "Taverne" license above, 


\section{Maastricht University}

Stefanie Kleimeier, Roald Versteeg

Project Finance as a Driver of Economic Growth in Low-I ncome Countries

$\mathrm{RM} / 09 / 011$

\section{METEOR}

Faculty of Economics and Business Administration Maastricht Research School of Economics

of Technology and Organization

P.O. Box 616

NL - 6200 MD Maastricht

The Netherlands 
Version: February 13, 2009

\title{
Project Finance as a Driver of Economic Growth in Low-Income Countries
}

\author{
Stefanie Kleimeiera,b, ${ }^{*}$ and Roald Versteega
}

\begin{abstract}
This study investigates the role of project finance as a driver of economic growth. We hypothesize that project finance is beneficial to the least developed economies as it compensates for any lack of domestic financial development. The contractual structure unique to project finance should lead to better investment management and governance. Investigating 90 countries from 1991 to 2005, we find support for our hypothesis. Project finance indeed fosters economic growth and this effect is strongest in low-income countries, where financial development and governance is weak.
\end{abstract}

JEL classification: F43, G15, G21, O16.

Keywords: project finance, economic growth, economic development, financial development, developing countries.

a Limburg Institute of Financial Economics, Maastricht University.

b METEOR, Maastricht University.

* Corresponding author:

Stefanie Kleimeier

Limburg Institute of Financial Economics

Faculty of Economics and Business Administration

Maastricht University

P.O. Box 616

6200 MD Maastricht

The Netherlands

Tel: +31-43-3883733, Fax: +31-43-3884875

email: s.kleimeier@finance.unimaas.nl. 


\section{Introduction}

Which type of finance is the optimal driver of economic development in developing countries? Already as early as 1911 Schumpeter stressed the importance of financial markets in understanding economic development. Ever after countless studies have been undertaken to exactly understand the link between finance, economic development and growth. According to one school of thought, financial development is an "overstressed determinant of economic growth" (Lucas, 1988:6). Miller (1998:14) counteracts "that financial markets contribute to economic growth is a proposition too obvious for serious discussion". To the supporters of the latter view, the correct question should not be if, but how financial development can affect economic growth. Financial development leads not only to an increase in the quantity of capital but, more importantly, also to an improvement in the quality of capital. It is through the quality of capital that finance contributes to growth.

In this study we provide new insights regarding whether and how financial development can affect economic growth by focusing on one specific financial instrument: project finance. The use of project finance has grown dramatically over the years from $\$ 12.5$ billion (bn) per annum in 1991 to $\$$ 113.4 bn in $2005 .{ }^{1}$ Financing almost 4,000 projects in 113 countries the total amount of project finance raised between 1991 and 2005 amounts to $\$ 1,077$ bn. While the US with $\$ 186.4$ bn accounts for most project finance (followed

\footnotetext{
${ }^{1}$ As reported by LPC Dealscan. The dollar amounts are nominal and reflect the debt portion in the financing of the projects.
} 
by Australia and the UK), this form of financing has also been used extensively in emerging economies: such as in Taiwan (\$ 64.2 bn), China (\$ 58.9 bn) and Malaysia ( $\$ 46.5$ bn). Compared to other regions, Asia Pacific attracts most project finance (combined: $\$ 459.8 \mathrm{bn}$ ). As this region is also characterized by strong economic growth, it is surprising that no study has yet investigated project finance as a driver of economic growth.

Project finance is designed to reduce of transaction costs, in particular those arising from a lack of information on possible investments and capital allocation, insufficient monitoring and exertion of corporate governance, risk management, and the inability to mobilize and pool savings. Project finance should thus have a clear impact on economic growth, especially there where financial development is shallow. Our empirical analysis of 90 countries from 1991 to 2005 confirms this hypothesis. Project finance is found to be a strong driver of economic growth in low-income countries where transaction costs are particularly high. Controlling for initial conditions and other economic factors, a move from the $25^{\text {th }}$ to the $75^{\text {th }}$ percentile in project finance will increase annual growth by 2.0 percentage points.

The remainder of our paper is structured as follows: Section 2 reviews the existing theoretical and empirical evidence of financial development as a driver of economic growth and motivates why project finance should be a particularly strong driver of growth in low-income countries. Section 3 
presents the data and methodology while section 4 discusses the results of the empirical analysis. Section 5 concludes.

\section{Financial development, project finance and economic growth}

\subsection{Theory and evidence on the finance-growth nexus}

In the classical literature the link between finance and growth is through capital accumulation or the quantity of capital: economic growth is the result of increases in innovation, human capital and physical capital. As finance develops, it increases the quantity of capital and thereby creates economic growth. However, as Schumpeter (1911) pointed out, this view ignores a very important channel. In his perception, finance stimulates growth not by creating more savings and thus increasing the quantity of capital, but rather by allocation savings better and stimulating technological innovation: increasing total factor productivity (TFP), e.g. improving the quality of the capital.

In theory, financial markets can stimulate the quality of capital in several ways (Levine, 1997). Firstly, well-developed markets improve resource allocation and allow easier access to capital for entrepreneurs, thus lowering their financial constraints and financing costs (Tobin and Brainard, 1963; Boyd and Prescott, 1986). Secondly, financial markets play a vital role

in corporate governance by dealing with agency costs and informational asymmetries (Bernanke and Gertler, 1989). Thirdly, markets facilitate the 
pooling and sharing of risks. Through financial markets, investors can diversify their portfolios and minimize idiosyncratic risk. In addition, markets allow not only for the insurance of liquidity risk through banks but even for intergenerational consumption smoothing through pension funds. Fourthly, markets mobilize and pool savings and fifthly they ease the exchange of goods and services. Empirical evidence supports the view that financial markets stimulate economic growth. King and Levine (1993a, 1993b) show that economic growth increases as the financial system develops and deepens while Levine and Zervos $(1996,1998)$ document that larger and better developed stock markets contribute directly to economic growth.

There are, however, few guidelines on how to develop financial markets when they are still nascent. This gives cold comfort to the large group of emerging economies that have yet to develop their financial markets. If such countries nevertheless want to increase their growth while still reforming their financial sector, they might simply consider importing finance from abroad in the form of international capital flows. International capital can provide many of the advantages of a domestic market: International capital flows can increase the relatively low capital stocks, can lower the relatively high costs of capital that most emerging economies are faced with (Bekaert and Harvey, 2000) and can increase the scope of risk diversification (Voth, 2003). 
As for domestic financial markets, it is the quality of international capital that matters, not the quantity. The direct quantity-effects of internationalization might not be very big² while liberalization often leads to financial crises which can severely destabilize the local economy (Allen and Gale, 1999; Krugman, 1999). Liberalization should therefore be carefully sequenced (McKinnon, 1991; Edwards, 1990) as not all capital is equal. 'Hot money' in the form of short-term foreign currency denominated debt if far more risky than long-term local currency denominated equity. ${ }^{3}$ An economy should first focus on those relatively safe capital flows. Only when its domestic markets are developed enough can it benefit from other riskier types of capital.

The question remains which types of capital are suitable for emerging economies when domestic financial markets are nascent and international capital flows are risky. Two candidates have been put forward in the literature: Portfolio equity investments and foreign direct investment (FDI). International equity inflows are known to reduce the cost of capital for domestic firms, increase risk sharing and stimulate the improvement of corporate governance (Claessens et al., 1995). However, a country can only receive equity inflows if the domestic stock market is well developed. As most

\footnotetext{
${ }^{2}$ Benefits amount to approximately a $0.5 \%$ permanent increase in consumption for developed economies (Mendoza and Tesar, 1998) and 1\% for emerging economies (Gourinchas and Jeanne, 2006). Market distortions can further reduce this benefit (Matsuyama, 2004) or can make it even negative (Boyd and Smith, 1997).

${ }^{3}$ Short-term foreign debt relative to foreign exchange reserves has actually been identified as the single most important predictor to financial crises by Rodrik and Velasco (1999).
} 
developing countries have at best a fledgling and still illiquid equity market (Knight, 1998), this puts severe limitations on the use of international equity financing. FDI, like equity, is long-term in nature and minimizes currencyand maturity-mismatches. It is also beneficial in terms of transfers of technology, managerial skills and labor practices, access to new markets and production networks and the import of corporate governance. Importantly, FDI does not rely on the existence of a well-developed domestic financial market and firms can in part substitute the domestic financial market through FDI (Hausmann and Fernández, 2000). Through FDI a firm exerts direct control over the operations, reduces informational asymmetries and can thus alleviate some of the problems associated with inadequate contract enforcement and poor protection of intellectual property rights.

Given the long list of benefits, it is not very surprising that FDI has been found to have a positive effect on economic growth (see e.g. Reisen and Soto, 2001). However, most studies do not find an unambiguously positive relation between FDI and growth. The effectiveness of FDI appears to be contingent on the economic and financial development of the domestic country indicating that even FDI is only beneficial if a certain threshold of development has been reached. Lack of human capital (Borensztein et al., 1998), underdevelopment of financial markets (Alfaro et al., 2004) or institutions (Durham 2004) and trade restrictions (Balasubramanyam et al., 1996) can prevent the positive effects of FDI to be disseminated to the local 
economy. For example, FDI can stimulate the import of good corporate governance. However, FDI can only do so when certain legal standards are present in the host country. During the Asian crisis, countries with better disclosure requirements had better stock price performance (Mitton, 2002) and the countries with the weakest outsider investor protection experienced the largest stock market and currency crashes (Johnson et al., 2000). In general, Blomström et al. (1992) show that FDI provides positive growth effects only for high-income countries but not for low-income countries. Similarly De Mello (1999) shows that only OECD countries are able to benefit from positive spillover effects of FDI as measured by TFP gains. The gains of FDI to developing countries are limited to quantity effects which, as we pointed out above, are not very big.

In sum, we perceive the evidence on the finance-growth nexus as follows. It is the quality and not the quantity of finance that matters. Finance creates spillover effects in terms of TFP gains that foster economic development and growth. Foreign sources of capital such as portfolio equity finance or FDI can also create positive spillovers, in the best case compensating for the absence of well-functioning domestic markets. However, even FDI, though generally considered one of the safest and most beneficial types of foreign capital, is much less effective in the least developed markets. In the next section we therefore set out to argue that the unique properties of 
project finance make it well suited to substitute an underdeveloped domestic financial market.

\subsection{The growth-enhancing properties of project finance}

Project finance can be defined as "the creation of a legally independent project company financed with equity from one or more sponsoring firms and non-recourse debt for the purpose of investing in a capital asset" (Esty, 2007). Project finance is generally used for new, stand-alone, complex projects with large risks and massive informational asymmetries. Nevertheless, sponsors' equity contributions are small and the bulk of the financing is provided in form of non-recourse, syndicated loan tranches. The lead banks become project insiders through working with the project sponsors during the initial screening and structuring phase and are responsible for funding the loan in the global syndicated loan market by attracting other banks to become members of a loan syndicate (Gatti et al., 2008). As these loans are non-recourse - e.g. they finance the project company with no or only limited support from the sponsors - the syndicate bears much of the project's business risk. Given the project's high leverage, business risk must be reduced to a feasible level. Here lies one of the key comparative advantages of project finance: It allows the allocation of specific project risks (i.e., completion and operating risk, revenue and price risk, and the risk of political interference or expropriation) to those parties best able to manage 
them (Brealey et al., 1996). Thus, project finance comprises not only financial arrangements dominated by non-recourse debt funded in the global syndicated loan market but also a large set of contractual arrangements aimed at risk management.

These specific characteristics of project finance enable it to substitute underdeveloped financial markets and emulate, in part, the desirable features of a well-developed market. Like any other type of finance, project finance is of course most successful in a transparent environment where contracts are respected because adjusting the structure of project finance to deal with market failures will be costly and imperfect (Ahmed, 1999). The important point is, however, that project finance still functions relatively well in the least developed countries (LDCs). Most other types of capital, such as FDI, are not very effective in substituting the market, making project finance an attractive choice for LDCs.

As stated earlier, the five main functions of a financial market are: (1) ex-ante information production and efficient allocation of capital, (2) ex-post monitoring of investments and exerting corporate governance, (3) facilitation of diversification and management of risk, (4) mobilization and pooling of savings and (5) facilitation of transactions (Levine, 1997). If markets are underdeveloped and do not function well in these areas the transaction costs of capital increase. For each of the five functions, we will show how the structure of project finance allows it to substitute the domestic market and 
control transaction costs. The advantages are especially pronounced in the fields of information production and corporate governance. ${ }^{4}$

First, consider transaction costs arising from a lack of information on possible investments and inefficient capital allocation. Ex-ante evaluation of investments is costly for individual investors. Financial intermediaries reduce the costs of acquiring and processing information and thereby improve resource allocation (Boyd and Prescott, 1986). Project finance reduces these costs as a syndicate of banks provides the majority of the funds and delegates the major screening and arranging tasks to the syndicate's lead banks. The project is separated from the sponsoring firm or firms and only a single investment rather than the overall sponsor(s) needs to be evaluated.

Furthermore, project finance can improve the efficiency of capital allocation as it targets sectors that are bottlenecks in LDCs. Take the example of an infrastructure investment structured as build-operate-transfer project finance. While most free cash flows are paid to the syndicate lenders and thus not reinvested locally during the operations phase of the project, the assets will ultimately be transferred to the government thereby putting technology and revenues into local hands. The newly acquired infrastructure itself can lead to improved economic growth (Sanchez-Robles, 1998). Generally, funds for large capital investments in developing countries are

\footnotetext{
${ }^{4}$ In contrast, Esty et al. (2003) develop a framework for assessing the development impact of investment projects. This framework takes a micro-level view and visualizes the impact of a project on each of its stakeholders. It applies to investment projects in general and is thus
} 
often only available from the public sector. While these institutions fund the initial investment, financing repair and maintenance during the project's operation can be problematic leading to temporary or even permanent shutdown of the facility (Buljevich and Park, 1999). Project finance can overcome this problem by explicitly taking these financing needs into account and can thus lead to a more effective allocation of capital.

These specific traits of project finance are very useful when information acquisition is costly and the market is opaque. The separation of the project from sponsor improves the transparency of the investment, thereby making it easier to screen. The unambiguous assignment of screening responsibilities to the lead banks limits free-riding on the information acquisition internalizes the costs of the screening and thus creates the appropriate incentives to screen. These lead banks can be expected to have superior screening skills due to their standing as sophisticated multinational banks ${ }^{5}$, their repeated entry into the project finance market and in some cases their regional specialization in developing countries.

applicable but not limited to project finance. Due to its more macro-oriented economic focus, we decide to follow Levine's (1997) framework instead.

${ }^{5}$ Leading banks in the project finance markets are typically headquartered in industrialized countries with a developed financial sector. Based on project finance league tables provided by LPC Dealscan (considering all project finance deals arranged from 1991 to 2005), the top10 project finance banks are RBS (UK), JP Morgan, Citibank, Bank of America (US), Mizuho Financial Group, Mitsubishi UFJ Financial Group (Japan), Calyon Corporate \& Investment Bank (part of Credit Agricole), BNP Parisbas (France), HSBC (Hong Kong) and Credit Swiss (Switzerland). Banks are listed by nationality and not by league-table ranking. 
Second, consider transaction costs arising from insufficient monitoring and exertion of corporate governance. Effective monitoring induces managers to maximize firm value which in turn improves the efficiency of the firm's resource allocation (Levine, 2006). The explicit corporate governance and risk management structure of project finance is well suited to serve as a substitute for domestic structures and institutions. ${ }^{6}$ Brealey et al. (1996), using the example of infrastructure projects, show that project finance has several characteristics specifically designed to deal with agency problems. These characteristics are largely independent of the legal framework and are thus likely to work when general corporate governance frameworks are not well developed: (1) Project finance lenders have a strong incentive to monitor due to high leverage and the non-recourse nature of their claim (Hainz and Kleimeier, 2008). (2) The separation of the project from the sponsoring firm improves corporate governance as management is decentralized and projectspecific incentives are created for managers (Laux, 2001) (3) Furthermore, the focus of the project company on a single investment reduces the risk of misallocation of funds regarding the initial investment (Brealey et al., 1996) while (4) the waste of free-cash flows during operation is reduced due to high leverage and the inclusion of a cash-waterfall as part of the contractual

\footnotetext{
${ }^{6}$ It has been suggested that project finance can also stimulate reform in a country (Ahmed, 1999), thereby paving the way for other types of finance. Although this offers many interesting avenues, it is not within the scope of this paper to pursue and test this implication.
} 
structure. (5) Finally, the extensive contractual structure increases transparency about the project, thereby improving governance.

The flexibility of project finance also allows the choice of a corporate structure which best suits the market conditions. The involved parties are to some extent free to choose the law that regulates the project (Harries, 1989; Ahmed, 1999). A logical choice is the law of the country where the major tangible assets are located. However, in the case of an emerging country it is possible to choose, for example, the US or UK to circumvent the problems association with a possibly not well developed local legal system.

Another problem that can arise in LDCs is political (or sovereign) risk, a cost that is especially difficult to deal with. As discussed above, even international capital like FDI that can substitute corporate governance on a firm level has difficulties when dealing with political risk on a national level. Although project finance also cannot fully mitigate this risk, there is some evidence it may at least reduce it. Hainz and Kleimeier (2008) show that development banks are particularly effective in reducing political risk and can act as political umbrellas when included in the syndicate. Indeed, they find that project finance is the preferred financing tool in countries with high political risk and poor corporate governance. Similarly, Esty and Megginson (2003) show that syndicates adjust their concentration to deal with sovereign risk and economic risk. In countries with low protection and high risk, 
syndicates are large to prevent strategic defaults; this at the cost of monitoring incentives that come with more concentrated debt ownership.

Third, consider transaction costs associated with cross-sectional risk diversification: when capital is scarce and investors are risk averse, investors will avoid risky high-return projects and seek out safe low-return projects. Thus, if investors cannot diversify cross-sectional risk, then savings will not flow towards high-return investments which can boost growth (Acemoglu and Zilibotti, 1997). Project finance will not alter the risk appetite of the local investors, but as international capital it is not limited by the same constraints and therefore more likely than domestic capital to flow to the abovementioned growth-enhancing projects.

Fourth and fifth, consider the transaction costs arising from the inability to mobilize and pool savings and to facilitate transactions. In many cases the required sums for an investment are larger than those offered by a single investor. The inability of the market to pool savings and link them to investments can lead to severe financing constraints. Closely related is the function of the market to facilitate transactions by acting as a middle man between individual investors and potential borrowers, reducing searching and screening costs. The absence of this function hampers financing (Ang, 2008). Project finance is specifically designed to deal with large investments and the syndicates normally consist of large (international) banks. Therefore it should not be hindered much by the inability to pool savings, nor by the 
inability to facilitate transactions. However, it has to be noted that the savings pooled and the transactions facilitated are those of the lenders' home countries, not those of the project's host country. Project finance can do very little to help improve the market's ability to pool domestic savings and facilitate domestic transactions. It can only help in meeting the need for large sums of money for single investments which cannot be met by domestically pooled savings.

In sum we conclude that project finance is very flexible and can easily be adapted to different economic and political environments. This flexibility allows project finance to substitute for underdeveloped financial markets. Its structure enhances ex-ante screening and ex-post corporate governance. Moreover, project finance is well suited to deal with political risk and suffers only minimally from the market's inability to manage risk, pool savings or facilitate transactions. These characteristics provide it comparative advantages in underdeveloped markets over most other types of capital. These advantages are, in our eyes, likely to stimulate growth in LDCs, as will be tested formally in the next sections.

\section{Data and methodology}

We will answer the question whether or not project finance is a driver of economic growth within a neo-classical growth framework, first developed in the Swan-Solow and Ramsey-Cass-Koopmans models. In summary, these 
models presume that the GDP per capita of each country converges towards its equilibrium. In two seminal papers Barro (1991) and Mankiw et al. (1992) derive an empirical specification for these models, based on the assumption that it is unlikely that a country is already at its steady state. In such a setting where countries are not already at their steady states, transitional dynamics, such as financial development, are an important determinant for economic growth. Our starting model is based on this empirical specification and visualizes growth in country i as a function of initial GDP, project finance $\mathrm{PF}$ and a set of further control variables $\mathrm{X}$ :

$$
\text { GROWTH }_{i}=\beta_{0}+\beta_{1} \ln \left(\text { INITIAL } \text { GDP }_{i}\right)+\beta_{2} \mathrm{PF}_{\mathrm{i}}+\sum_{\mathrm{j}} \beta_{2+\mathrm{j}} \mathrm{X}_{\mathrm{i}, \mathrm{j}}
$$

We estimate equation (1) in two specifications: In our baseline specification the selected control variables $\mathrm{X}$ include schooling, population growth, government consumption, and a dummy for the sub-Saharan countries in the sample. In our extended specification, a larger set of control variables will be used measuring economics, population and institutional characteristics in addition. The set of chosen controls follows Alfaro et al. (2004) and comprises the most common variables used in the literature. In a refinement of our model, we will also (1) consider FDI and contrast its effect on growth with that of project finance and (2) investigate the effect of project finance on growth dependent on the economic development of the recipient countries. These refinements will be motivated in more detail in section 4 . As a consequence of our choice of control variables, our data is split into two sets 
of countries. The first dataset, consisting of 90 countries, includes the variables used in our baseline specification. Our second dataset reduces to 71 countries, due to limited data availability of some the variables in our extended specification. ${ }^{7}$

Growth is measured as the log-change in real GDP per capita in constant US dollar and obtained from the World Bank's (2008) World Development Indicators (WDI) database. Correspondingly, initial GDP reflects the log of the level of constant US dollar GDP per capita at the beginning of the growth period.

We obtain data on project finance from the Loan Pricing Corporation's Dealscan database. We select all deals with the purpose 'project finance' and obtain the total volume of project finance deals from the 'Totals \& Averages Report'. The deals are converted to US dollar and aggregated by borrower country and year of deal signing. Note that the deal volume reflects only the debt financing raised for the project but not the equity investment. We focus on project finance deals signed between January 1, 1991 and December 31, 2005 as Dealscan's coverage in earlier years is limited to a few countries and thus not representative.

The measure of net FDI inflows comes from the WDI. Thus, for both project finance and FDI, we relate the cumulate volume of financing to the growth over the same period to limit the measurement error of the data (Lane and Milesi-Ferretti, 2001). The schooling variable is measured as the

${ }^{7}$ The appendix contains a complete overview of the countries in both datasets. 
average total years of schooling in the adult population and comes from Barro and Lee (1996, 2001); the law variable refers to the 'rule of law' as measured by the International Country Risk Guide (ICRG); the black market premium is the difference between the parallel and official exchange rate, retrieved from the Global Development Network database at New York University. The other variables come from the WDI: government consumption measures the central government's total government expenditures to GDP; openness is defined as imports plus exports over GDP; inflation is calculated as the percentage change in the deflator; population growth is defined as annual percentage growth. Income and location dummies follow the World Bank's country classification.

The variables used in the regressions are defined in the following manner. Missing initial values are substituted by the adjoining year if possible. Averages are calculated if at least 3 out of 5 data points are available in the respective 5-year period. Project finance and FDI are the cumulative net inflows over the regression period as a share of GDP. Likewise, population growth is the average growth rate for the regression period. The schooling variable is defined as the log of $(1+$ total years of schooling). The black market variable is the log of $(1+$ black market premium). The inflation variable is the $\log$ of $(1+$ average inflation). Openness is defined as the log of (average exports plus imports as a share of GDP). 
We estimate equation (1) as an OLS regression for a panel of three 5year periods of 1991 to 1995,1996 to 2000 and 2001 to 2005 and for a crosssection of countries over a 15-year period of 1991 to 2005. To control for possible endogeneity we also estimate a 3SLS instrumental variable (IV) model. As has been pointed out in previous literature ${ }^{8}$ it is quite likely that capital - such as project finance - flows mainly to countries that experience high growth rates. If this is the case, simple OLS regressions will overstate the true effect of project finance on economic growth. IV analysis provides a solution to this problem.

\section{Results}

\section{1. Growth and project finance}

Table 1 provides a first impression about the link between project finance and economic growth. In the 90 countries contained in our baseline sample, $\$ 908$ bn of funds were raised in form of project finance between 1991 and 2005. Covering $84 \%$ of the total of $\$ 1,077$ bn raised worldwide, our sample can be said to be representative for the global project finance market. When comparing the annual volume of newly signed project finance deals in real US\$ (2005), it becomes clear that the use of project finance has increased over time from $\$ 16$ bn in 1991 to just und $\$ 69$ bn in 2005 . The volume of project finance loans is highest just before the Asian crisis in 1997 and 1998 with $\$ 108$ bn and $\$ 110$ bn per year, respectively. While the total numbers

\footnotetext{
${ }^{8}$ See for example Nair-Reichert and Weinhold (2001) and Li and Liu (2005).
} 
are substantial, project finance is relatively small in comparison to the GDP of the recipient country. The size of new project finance deals amounts in most years to less than $0.01 \%$ of GDP. Even in countries where the use of project finance is highest, new project finance deals do not amount to more than $0.2 \%$ of GDP. For comparison, FDI inflows are typically in the range of $1 \%$ to $5 \%$ of GDP. Nevertheless Table 1 shows a remarkable trend. Highgrowth countries, as measured by the top growth-quartile, raise substantially more funds in form of project finance than low-growth countries, the bottom growth-quartile: $\$ 259.5$ bn versus $\$ 16.5$ bn in total from 1991 to 2005 . Also in relative terms high-growth countries have more project finance inflows than both low-growth countries and the average country in the sample. Although it is too early at this point to postulate any causal relations, it does appear from the data that more project finance is associated with higher growth. In the remainder of this section, we will investigate whether this initial finding is robust.

[Insert Table 1 about here]

Table 2 presents detailed descriptive statistics of our dependent and independent variables for our baseline sample of 90 countries in Panel A as well as for our reduced sample of 71 countries in Panel B. Both samples are remarkably similar in terms of average growth, project finance and FDI stocks, schooling, government consumption and regional coverage of SSA countries. The reduced sample contains, however, somewhat larger countries 
in terms of initial GDP. During our sample period, countries typically grow at about $1 \%$ annually. However, there is considerable variation in the growth rates across different countries, ranging from $-5.35 \%$ for Congo to $8.72 \%$ average annual growth in China. Cumulative inflows - e.g. stocks - of project finance amount to $0.05 \%$ of GDP on average while cumulative FDI flows are far more substantial with more than $40 \%$ of GDP for the average country. But these averages can be misleading as stocks of project finance and inward FDI also vary widely over the sample. Malaysia (0.54\%) and the Philippines (0.37\%) have the most project finance to GDP, while Belgium (260\%) and Lesotho (206\%) lead in terms of FDI. A comparison of Table 1 and 2 lays bare a general trend in the data. Although the total project finance flows are substantial and the large growth notwithstanding, flows of project finance remain rather small relative to the GDP of the recipient country. The descriptive statistics of the other variables are in line with those of previous studies and - as they only serve as control variables in our analysis - will not be explicitly discussed here.

\section{[Insert Table 2 about here]}

Table 3 shows the results of an OLS estimation of equation (1) for a panel of three 5-year growth periods of 1991-1995, 1996-2000 and 2001-2005. Regressions 1, 3, 5 and 7 show the baseline specification for a sample of 90 countries with the selected control variables which include schooling, population growth, government consumption, and a dummy for the SSA 
countries. In regressions 2, 4, 6 and 8, institutional quality (law), the black market premium, inflation, and the trade volume (openness) have been added and the sample drops to 71 countries.

First consider regressions 1 and 2 which exclude project finance and thus allow us to compare our results to those generally reported in the empirical growth literature. Initial income has a significant negative impact on growth, indicating that (conditional) convergence is present. Furthermore, sub-Saharan countries and countries that experience high inflation or high population growth face lower GDP growth, while more schooling and a better rule of law have a significant positive effect on economic growth. These results are in line with the existing evidence in the economic growth literature.

Turning to project finance, the main results reveal that project financial is not unambiguously correlated with economic growth. Regressions 3 and 4 include our project finance measure and show that, although positive, project finance is not significantly correlated with growth. As we postulate above that the special characteristics of project finance will be most beneficial in LDCs with a weak domestic financial system, this result is not surprising. It is likely that project finance is only significant contingent on the host country's economic development, e.g. its income level. Therefore, regression 5 and 6 interact project finance with the country's income level, identifying the effect of project finance on low-, middle- and high-income countries. The 
results corroborate our argument. In general project finance is shown to have a positive impact on growth, but the effect is only significant for the lowincome countries and not in the middle- and high-income countries.

To assess the quantitative impact of project finance on economic growth in a low-income country, consider the example of Uruguay, Ghana, and India. Uruguay currently has no project finance, ranking it around the $25^{\text {th }}$ percentile; Ghana, with $0.046 \%$ project finance to GDP, is very close to the average; and India, with $0.057 \%$ project finance to GDP, is located at the $75^{\text {th }}$ percentile. Using the coefficients of regression 6 , one can calculate the increase in growth when a country moves from low levels of project finance to higher levels of project finance. If a country increases its project finance from the minimum (Uruguay) to the average level (Ghana), it will raise annual growth by 1.6 percentage points over the 15 -year period. If it raises project finance equal to the $75^{\text {th }}$ percentile (India), it will increase growth by 2.0 percentage points. When this is compared to the average realized growth rate of $2.6 \%$, it becomes clear that how substantial the gains from project to growth can be.

These growth-effects of project finance might be driven by benefits unique to project finance. Alternatively, the growth-effects might be driven by more general spillovers of project finance as foreign capital. In order to distinguish these two alternatives, we include a measure of FDI in regressions 7 and 8 . Note that in low-income countries, project finance will 
generally constitute part of FDI. As pointed out in section 2 above, the most prominent lead banks in the project finance market are headquartered in industrialized countries. Thus, while a project in a high-income country might well be financed by a syndicate of domestic banks, in low-income countries the syndicate will likely be dominated by foreign banks. ${ }^{9}$ By including FDI as an additional variable in our regressions we control for the fact the foreign capital can in general be beneficial for growth. Any remaining growth-effects of project finance are probably driven by features that are unique to its structure. We find that FDI is highly significant for all income levels and that project finance remains significant for low-income countries. This indicates that in low-income countries it is indeed project finance with its unique features that is beneficial to the country's growth.

$$
\text { [Insert Table } 3 \text { about here] }
$$

\subsection{Robustness checks}

Until now we have not yet addressed the potential problem of endogeneity. As has been pointed out in previous literature it is quite likely that project finance, or foreign capital in general, flows mainly to those countries that experience high growth rates. If this is the case, the results of Table 3 will overstate the true effect of project finance on economic growth. In the worst case, the results are caused by reverse causality. Robinson (1952)

\footnotetext{
${ }_{9}$ Ahmed (1999) shows that $77 \%$ of the total costs of IFC-supported projects are financed by international sources and that this share declines as domestic financial markets improve.
} 
argues for instance that growth is not caused by financial development but that finance simply develops because the economy grows. IV analysis provides a solution to this problem. Thus, valid instruments for both our financial variables have to be constructed.

The first logical candidates are the lagged values of project finance and FDI. By construction these variables are predetermined with respect to current growth, preventing reverse causality. And as flows of capital, like project finance and FDI, are quite persistent over time, lagged values are good predictors for future capital flows. Wheeler and Mody (1992), for example, show that FDI is self-propagating: large existing stocks of capital stimulate further FDI flows into that country. As an additional instrument we include the real exchange rate. All of FDI and much of project finance comes from abroad. A low real exchange rate decreases the relative local costs while increasing the relative foreign wealth, making investments in the local economy more attractive for foreigners (Bloningen, 1997; Froot and Stein, 1991). Klein and Rosengren (1994) provide empirical support that the real exchange rate is a determinant of investment flows.

Table 4 reports the IV regressions using lagged values of FDI and project finance and the real exchange rate as instruments. The instruments prove to be jointly significant in the first stage in all cases ${ }^{10}$ and the Sargan test for overidentifiying restrictions indicates that the instruments are relevant. Compared to Table 3, the coefficients increase considerably in 
value. This may result from potential measurement errors in our financial variables, driving the coefficients in the OLS to zero. IV corrects this error. In any case, as the significance is in general unaltered, it can be concluded that the results are robust.

[Insert Table 4 about here]

Having shown that our results are robust even when considering endogeneity, we return to the setting of Table 3 and re-estimate the regressions based on a sample that excludes countries with extremely high levels of project finance. More specifically, we exclude all observations which belong to the top-5\% in terms of project finance to GDP. ${ }^{11}$ Results are reported in Table 5 and we confirm our finding of project finance as a driver of economic growth. In terms of the significance of our project finance variables, the results are even stronger now that outliers are excluded. We now even find some evidence, in regression 1, that project finance is unconditionlly associated with higher economic growth. Regressions 3 to 6 confirm that this overall effect is mainly driven by low-income countries. Compared to Table 3, the coefficients of project finance are more significant and larger indicating that outliers do not drive our main results in Table 3. As in Table 3, the inclusion of FDI does not reduce the effect of project finance. Finally, in Table 6, we control for endogeneity and outliers

\footnotetext{
${ }^{10}$ Results not reported for brevity.

11 The distribution of project finance is skewed with several countries having no project finance. We therefore focus only on outliers in the right tail of the distribution.
} 
simultaneously and find - in line with our previous results - that project finance is associated with higher economic growth in low-income countries.

[Insert Table 5 and 6 about here]

\section{Conclusion}

In this study we examine the finance-growth nexus with specific focus on project finance. Based on the existing theoretical and empirical evidence on the impact of finance and growth, we hypothesize that project finance has the right features to stimulate growth. The benefits of foreign capital are known to depend on the development of the domestic financial sector. Countries receiving foreign capital inflows should realize that the quality of capital matters more than its quantity. In this sense, not all capital is equal. Countries with underdeveloped financial sectors should therefore focus on safe long-term capital before encouraging more advanced forms of capital inflows. We argue that project finance can adjust to less-than-favorable environments in least developed countries and might even substitute for the lack of institutional and financial development. Our results show that project finance promotes growth in particular in low-income countries. Moving from the $25^{\text {th }}$ to the $75^{\text {th }}$ percentile in the use of project finance reveals that these countries can gain an up to 2 percentage points increase in annual economic growth, ceteris paribus. This result is robust to outliers as well as possible reverse causality. 
Our evidence is consistent with the view that project finance has a superior ability to facility information production and good project governance. The structure of project finance leads to extensive and effective screening and project finance is also likely to flow to growth-enhancing industries. With regards to corporate governance, project finance creates transparency combined with strong monitoring incentives for the investment which are independent of any external corporate governance environment. Overall, project finance is an effective tool to deal with high-risk environments. Our results lead us to wonder whether project finance can also stimulate financial development itself, paving the way for other sources of international finance. More evidence is required to answer this question, opening up new avenues for future research.

\section{Appendix}

\subsection{Countries included in samples}

Algeria, Australia, Austria, Bangladesh, Belgium, Benin*, Bhutan*, Bolivia, Brazil, Burundi*, Cameroon, Canada, Chile, China, Colombia, Costa Rica, Democratic Republic of Congo, Denmark, Dominican Republic, Ecuador, Egypt, El Salvador, Finland, France, Gambia, Germany, Ghana, Greece, Guatemala, Guyana*, Haiti*, Honduras, Hungary, Iceland*, India, Indonesia, Iran, Ireland, Israel*, Italy, Jamaica*, Japan, Jordan, Kenya, Kuwait*, Lesotho*, Malawi, Malaysia, Mali, Mauritania*, Mauritius*, 
Mexico, Mozambique, Nepal*, Netherlands, New Zealand, Nicaragua, Niger*, Norway, Pakistan, Panama*, Paraguay, Peru, Philippines, Poland, Portugal, Republic of Congo, Rwanda*, Senegal, Sierra Leone*, Singapore*, South Africa, Spain, Sri Lanka, Swaziland*, Sweden, Switzerland, Syrian Arab Republic, Thailand, Togo, Trinidad and Tobago, Tunisia, Turkey, Uganda, United Kingdom, USA, Uruguay, Venezuela, Zambia, Zimbabwe.

* indicates that a country is only included in the baseline regression sample but not in the extended regression sample.

\subsection{Data sources and variable definitions}

PF: Volume of all project finance deals signed per country. Source: Loan Pricing Corporation's Dealscan database. For the lagged values of PF used as instruments, we revert to data provided in 2003 by Euromoney, the previous provider of the Dealscan database. Whereas the coverage in later years is consistent in terms of PF volume with Dealscan, Euromoney's coverage prior to 1990 s is far more complete.

GDP and GDP growth: Real GDP per capita (growth) in constant 2000 US\$. Source: World Development Indicators (WDI), Worldbank (2008).

Income dummies: Dummies indicating if a country belongs to the low-, middle-, or high-income group according to the World Bank's country classification. Source: World Bank. 
SSAD: Dummy indicating countries geographically located in sub-Saharan Africa according to the World Bank's country classification. Source: World Bank.

Schooling: Average years of total schooling of the adult population. Source: Barro and Lee (1996, 2001), http://www.cid.harvard.edu/ciddata/ciddata.html. Population growth: Annual population growth in percent. Source: WDI, World Bank.

Government consumption: Total expenditure of the central government as a share of GDP; including both current and capital expenditures, excluding net financing. Source: WDI, World Bank.

Law: Average level of law and order. The variable ranges from 0 to 12 with higher values indicating better law and order. Source: International Country Risk Guide.

Black market premium: Calculated as the parallel exchange market relative to the official market; (parallel exchange rate / official exchange rate - 1) * 100. Source: New York University's Global Development Network Growth Database, http://www.nyu.edu/fas/institute/dri/

Inflation: Inflation as a percentage, measured as the change in the GDP deflator. Source: WDI, World Bank.

Openness: Calculated as the sum of the volume of imports and exports relative to GDP; (imports + exports)/GDP. Source: WDI, World Bank.

FDI: Net foreign direct investment inflows. Source: WDI, World Bank. 


\section{References}

Acemoglu, D. and F. Zilibotti. (1997) Was Prometheus unbound by chance? Risk, diversification, and growth. Journal of Political Economy, 105, 709-775.

Ahmed, P.A., (1999). Project Finance In Developing Countries: IFC's Lessons Of Experience. Washington DC: International Finance Corporation.

Alfaro, L., A. Chanda, S. Kalemli-Ozcan and S. Sayek. (2004) FDI and economic growth: the role of local financial markets. Journal of International Economics, 64, 89-112.

Allen, F. and D. Gale. (1999) Bubbles, Crises, and Policy. Oxford Review of Economic Policy, 15, pp. 9-18.

Ang, J. (2008) A survey of recent developments in the literature of finance and growth. Journal of Economic Surveys. 22, 536-576.

Balasubramanyam, V., M. Salisu, and D. Sapsford. (1996) Foreign direct investment and growth in EP and IS countries. Economic Journal, 106, $92-105$.

Barro, R. (1991) Economic growth in a cross section of countries. Quarterly Journal of Economics, 56, 407-443.

Barro, R. and J.-W. Lee. (1996) International measures of schooling years and schooling quality. American Economic Review, 86, 218-223.

Barro, R. and J.-W. Lee. (2001) International data on educational attainment: updates and implications. Oxford Economic Papers, 3, 541-563. 
Bekaert, G., and C. Harvey. (2000) Foreign speculators and emerging equity markets. The Journal of Finance, 55, 565-613.

Bernanke, B. and M. Gertler. (1989) Agency costs, net worth, and business fluctuations. American Economic Review, 79, 14-31.

Blomström, M., R. Lipsey and M. Zejan, (1994). What explains developing country growth? In W. Baumol, R. Nelson and E. Wolff (Eds.), International Convergence of Productivity, London: Oxford University Press, 243-260.

Bloningen, B. (1997) Firm-specific assets and the link between exchange rates and foreign direct investment. American Economic Review, 87, 447-465.

Borensztein, E., J. De Gregorio and J-W. Lee. (1998) How does foreign direct investment affect economic growth? Journal of International Economics, $45,115-135$.

Boyd, J. and B. Smith. (1997) Capital market imperfections, international credit markets, and nonconvergence. Journal of Economic Theory, 73, $335-364$.

Boyd, J.H. and E.C. Prescott. (1986) Financial intermediary-coalitions. Journal of Economic Theory, 38, 211-232.

Brealey, R., I. Cooper, and M. Habib. (1996) Using project finance to fund infrastructure investments. Journal of Applied Corporate Finance, 9, 2538. 
Buljevich, E.C. and Y.S. Park, (1999). Project Financing and the International Financial Markets. Norwell, MA: Kluwer Academic Publishers.

Claessens, S., M. Dooley and A. Warner. (1995) Portfolio capital flows: hot or cold? World Bank Economic Review, 9, 153-174.

De Mello, L. (1999) Foreign direct investment-led growth: evidence from time series and panel data. Oxford Economic Papers, 51, 133-151.

Durham, J. (2004) Absorptive capacity and the effects of foreign direct investment and equity foreign portfolio investment on economic growth. European Economic Review, 48, 285-306.

Edwards, S. (1990) The sequencing of economic reform: analytical issues and lessons from Latin America. The World Economy, 13, 1-14.

Esty, B.C., (2007). An Overview of Project Finance \& Infrastructure Finance2006 Update. Boston: Harvard Business School Publishing.

Esty, B.C. and W.L. Megginson. (2003) Creditor rights, enforcement, and debt ownership structure: Evidence from the global syndicated loan market. Journal of Quantitative and Financial Analysis, 38, 37-59.

Esty, B.C., F.J. Lysy and C. Ferman, (2003). An Economic Framework for Assessing Development Impact. Boston: Harvard Business School Publishing.

Froot, K. and J. Stein. (1991) Exchange rates and foreign direct investment: an imperfect capital market approach. Quarterly Journal of Economics, 106, 1191-1217. 
Gatti, S., S. Kleimeier, W.L. Megginson and A. Steffanoni. (2008) Arranger certification in project finance. Working paper.

Gourinchas, P. and O. Jeanne. (2006) The Elusive Gains from International Financial Integration. Review of Economic Studies, 73, 715-741.

Hainz, C. and S. Kleimeier. (2008) Project finance as a risk-management tool in international syndicated lending. Working paper.

Harries, H. (1989). Project financing: avoiding six basic weaknesses. In N. Horn (Ed.), The Law Of International Trade Finance, Leiden: Kluwer Law and Taxation Publishers.

Hausmann, R. and E. Fernandéz-Arias. (2000) Foreign direct investment: good cholesterol? Working Paper.

Johnson, S., P. Boone, A. Breach and E. Friedman. (2000) Corporate governance in the Asian financial crisis. Journal of Financial Economics, 58, 141-186.

King, R. and R. Levine. (1993a) Finance and growth: Schumpeter might be right. The Quarterly Journal of Economics, 108, 717-737.

King, R. and R. Levine. (1993b) Finance, entrepreneurship, and growth: theory and evidence. Journal of Monetary Economics, 32, 513-542.

Klein, M. and E. Rosengren. (1994) The real exchange rate and foreign direct investment in the United States: relative wealth vs. relative wage effects. Journal of International Economics, 36, 373-389. 
Knight, M. (1998) Developing countries and the globalization of financial markets. World Development, 26, 1185-2000.

Krugman, P. (1999) Balance sheets, the transfer problem, and financial crises. International Tax and Public Finance, 6, 459-472.

Lane, P. and G.M. Milesi-Ferretti. (2001) The external wealth of nations: measures of foreign assets and liabilities for industrial and developing countries. Journal of International Economics, 55, 263-294.

Laux, C. (2001) Project-specific external financing and headquarters monitoring incentives. Journal of Law, Economics, and Organization, 17 $397-412$.

Levine, R. (1997) Financial Development and economic growth: views and agenda. Journal of Economic Literature, 35, 688-726.

Levine, R. (2006) Finance and growth: Theory and evidence. In P. Aghion and S. Durlauf (Eds.), Handbook of Economic Growth, edition 1, volume 1, Amsterdam: Elsevier, 865-934.

Levine, R. and S. Zervos. (1996) Stock markets development and long-rungrowth. World Bank Economic Review, 10, 323-339.

Levine, R. and S. Zervos. (1998) Stock markets, banks, and economic growth. American Economic Review, 88, 537-558.

Li, X. and X. Liu. (2005) Foreign direct investment and economic growth: An increasingly endogenous relationship. World Development, 33, 393-407. 
Lucas, R. (1988) On the mechanics of economic development. Journal of Monetary Economics, 22, 3-42.

Mankiw, G., D. Romer and D. Weill. (1992) A contribution to the empirics of economic growth. Quarterly Journal of Economics, 107, 407-437.

Matsuyama, K. (2004) Financial market globalization, symmetry-breaking and endogenous inequality of nations. Econometrica, 72, 853-884.

McKinnon, R., (1991). The Order of Economic Liberalization: Financial Control in the Transition to a Market Economy. Baltimore: Johns Hopkins University Press.

Mendoza, E., and L. Tesar. (1998) The international ramifications of tax reforms: supply-side economics in a global economy. American Economic Review, 88, 226-245.

Miller, M.H. (1998) Financial markets and economic growth. Journal of Applied Corporate Finance, 11, 8-14.

Mitton, T. (2002) A cross-firm analysis of the impact of corporate governance on the East Asian financial crisis. Journal of Financial Economics, 64, $215-241$.

Nair-Reichert, U. and D. Weinhold. (2001) Causality tests for cross-country panels: A new look at FDI and economic growth in developing countries. Oxford Bulletin of Economics and Statistics, 63, 153-171.

Reisen, H. and M. Soto. (2001) Which types of capital inflows foster developing-country growth? International Finance, 4, 1-14. 
Robinson, J., (1952). The generalization of the general theory. In: The Rate of Interest and Other Essays, London: Macmillan Press, 67-142.

Rodrik, D. and A. Velasco, (1999). Short-term capital flows. In B. Pleskovic and J. Stiglitz (Eds.), Annual World Bank Conference on Development Economics, New York: World Bank, 59-90.

Sanchez-Robles, B. (1998) Infrastructure investment and growth: some empirical evidence. Contemporary Economic Policy, 16, 98-108.

Schumpeter, J., (1911). Theorie der wirtschaftlichen Entwicklung. Leipzig: Duncker \& Humblot.

Tobin, J. and W. Brainard. (1963) Financial intermediaries and the effectiveness of monetary control. American Economic Review, 53, 383400.

Voth, H.-J. (2003) Convertibility, currency controls and the cost of capital in Western Europe. International Journal of Finance and Economics, 8, $255-276$.

Wheeler, D. and A. Mody. (1992) International investment location decisions: the case of US firms. Journal of International Economics, 33, 57-76.

World Bank, (2008). World Development Indicators on CD-ROM. Washington DC: The World Bank. 


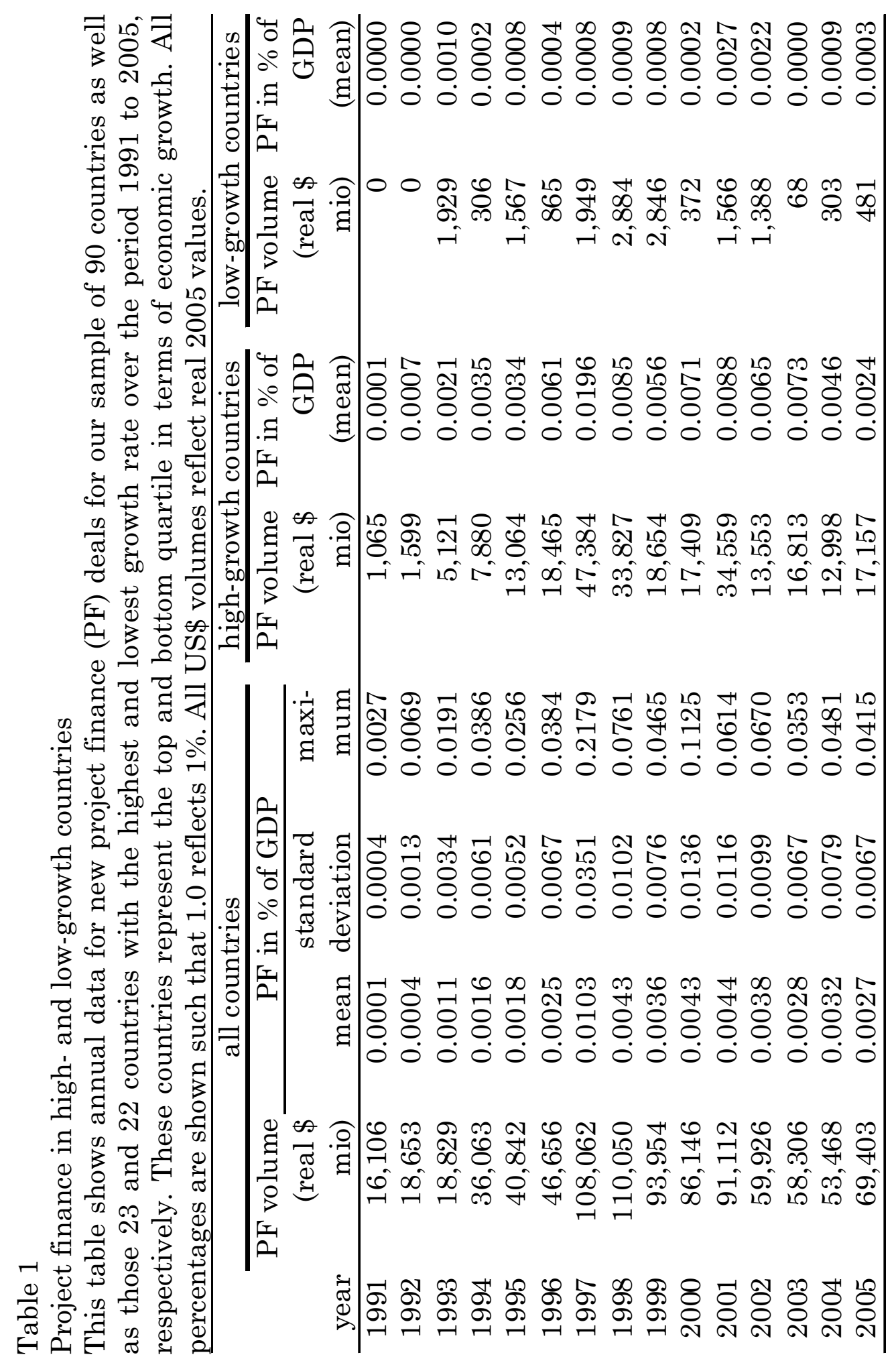




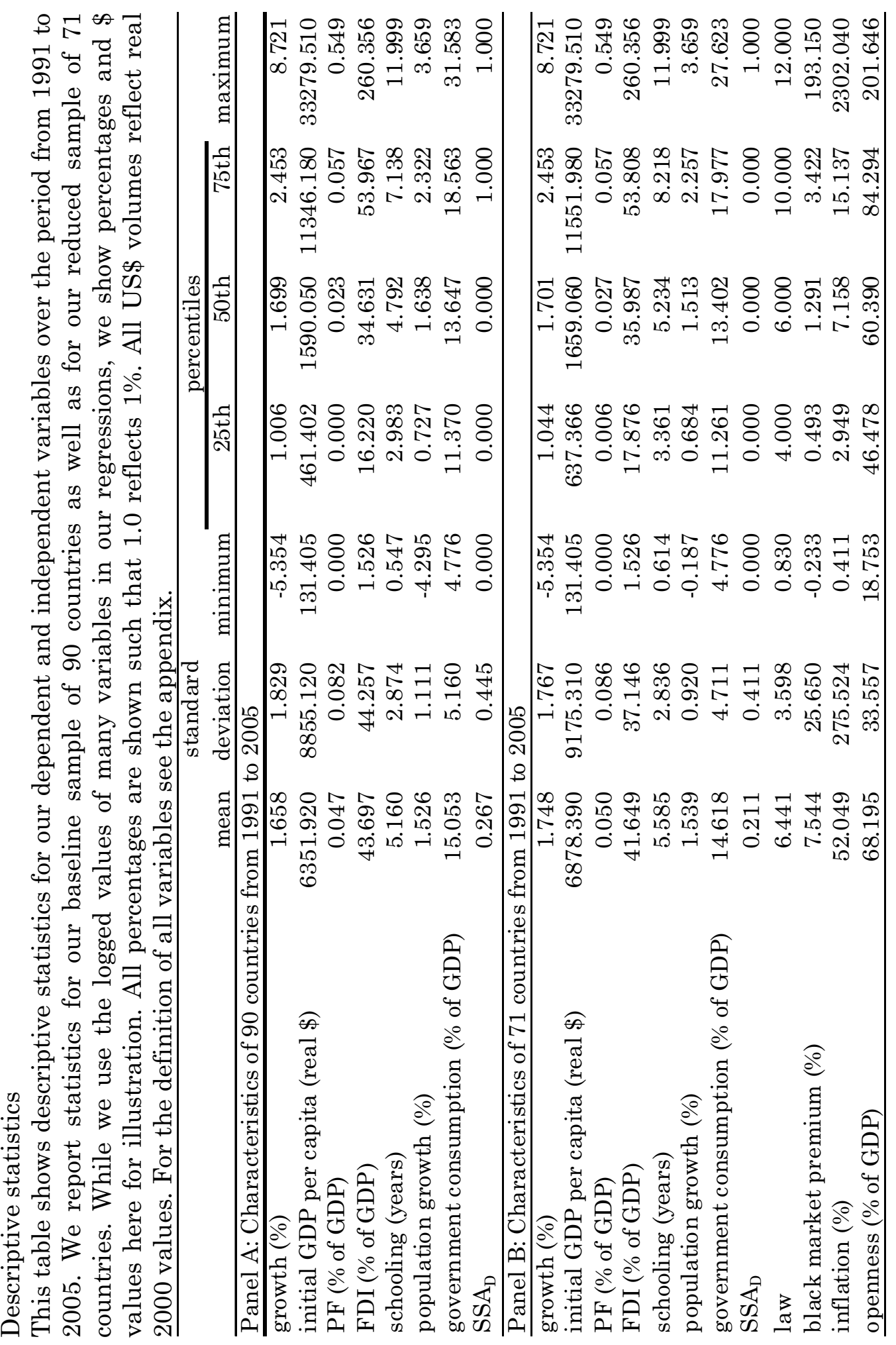


Table 3

The impact of project finance on economic growth

The dependent variable is the growth rate. We report the analysis of the project finance-growth nexus based on panel regressions using three 5-year growth periods from 1991 to 1995, 1996 to 2000 and 2001 to 2005 estimated with OLS. For each independent variable, the first row reports the estimated coefficient and the second row reports the t-statistic. ${ }^{* * *}, * *$ and $*$ indicate significance at $1 \%, 5 \%$ and $10 \%$ level respectively. The subscript $\mathrm{D}$ indicates a dummy variable. For the definition of all variables see the appendix.

\begin{tabular}{|c|c|c|c|c|c|c|c|c|}
\hline & Reg 1 & $\operatorname{Reg} 2$ & Reg 3 & Reg 4 & Reg 5 & Reg 6 & $\operatorname{Reg} 7$ & Reg 8 \\
\hline \multirow[t]{2}{*}{ constant } & $0.045^{* * *}$ & $0.094^{* * *}$ & $0.044 * * *$ & $0.093 * * *$ & $0.045^{* * *}$ & $0.087 * * *$ & $0.044^{* * *}$ & $0.083 * * *$ \\
\hline & 3.743 & 6.347 & 3.578 & 6.239 & 3.545 & 5.619 & 3.579 & 5.362 \\
\hline \multirow[t]{2}{*}{ GDP } & $-0.005 * * *$ & $-0.009 * * *$ & $-0.004 * *$ & $-0.009 * * *$ & $-0.005 * * *$ & $-0.009 * * *$ & $-0.005 * * *$ & $-0.008 * * *$ \\
\hline & -2.663 & -4.937 & -2.455 & -4.713 & -2.673 & -4.371 & -2.604 & -4.388 \\
\hline \multirow[t]{2}{*}{$\mathrm{PF}$} & & & 5.546 & 1.615 & & & & \\
\hline & & & 1.353 & 0.416 & & & & \\
\hline \multirow[t]{2}{*}{$\mathrm{PF}^{*}$ low income country $\mathrm{D}_{\mathrm{D}}$} & & & & & $16.449 *$ & $35.239 * *$ & 17.224 * & $35.104 * *$ \\
\hline & & & & & 1.753 & 2.440 & 1.870 & 2.462 \\
\hline \multirow[t]{2}{*}{$\mathrm{PF}^{*}$ middle income country $\mathrm{D}_{\mathrm{D}}$} & & & & & 1.654 & -1.237 & 0.657 & -0.657 \\
\hline & & & & & 0.361 & -0.308 & 0.146 & -0.165 \\
\hline \multirow[t]{2}{*}{$\mathrm{PF}^{*}$ high income country $_{\mathrm{D}}$} & & & & & 21.243 & 12.664 & 14.924 & 11.393 \\
\hline & & & & & 1.503 & 0.866 & 1.066 & 0.788 \\
\hline \multirow[t]{2}{*}{ FDI } & & & & & & & $0.027 * * *$ & $0.023 * *$ \\
\hline & & & & & & & 3.327 & 2.479 \\
\hline \multirow[t]{2}{*}{ schooling } & 0.011 * & 0.003 & 0.010 * & 0.003 & $0.011 * *$ & 0.004 & 0.009 & 0.004 \\
\hline & 1.921 & 0.527 & 1.748 & 0.455 & 2.001 & 0.680 & 1.555 & 0.665 \\
\hline \multirow[t]{2}{*}{ population growth } & -0.119 & $-0.678 * * *$ & -0.120 & $-0.682 * * *$ & -0.110 & $-0.672 * * *$ & -0.115 & $-0.621 * * *$ \\
\hline & -1.299 & -3.126 & -1.308 & -3.136 & -1.200 & -3.101 & -1.275 & -2.891 \\
\hline \multirow[t]{2}{*}{ government consumption } & 0.003 & 0.000 & 0.003 & 0.000 & 0.003 & -0.001 & 0.003 & 0.000 \\
\hline & 1.242 & 0.063 & 1.293 & 0.091 & 1.201 & -0.284 & 1.195 & -0.148 \\
\hline \multirow[t]{2}{*}{$\mathrm{SSA}_{\mathrm{D}}$} & $-0.021 * * *$ & $-0.024 * * *$ & $-0.020 * * *$ & $-0.023 * * *$ & $-0.021 * * *$ & $-0.024 * * *$ & $-0.022 * * *$ & $-0.024 * * *$ \\
\hline & -4.800 & -5.238 & -4.505 & -5.065 & -4.611 & -5.317 & -4.931 & -5.406 \\
\hline \multirow[t]{2}{*}{ law } & & $0.001 *$ & & 0.001 * & & 0.001 & & 0.001 \\
\hline & & 1.944 & & 1.877 & & 1.463 & & 1.313 \\
\hline \multirow[t]{2}{*}{ black market premium } & & 0.004 & & 0.004 & & 0.006 & & 0.007 \\
\hline & & 0.432 & & 0.465 & & 0.624 & & 0.795 \\
\hline \multirow[t]{2}{*}{ inflation } & & $-0.025 * * *$ & & $-0.025 * * *$ & & $-0.024 * * *$ & & $-0.024 * * *$ \\
\hline & & -6.678 & & -6.664 & & -6.373 & & -6.616 \\
\hline \multirow[t]{2}{*}{ openness } & & 0.001 & & 0.001 & & 0.003 & & 0.000 \\
\hline & & 0.439 & & 0.332 & & 0.897 & & -0.132 \\
\hline observations & 270 & 213 & 270 & 213 & 270 & 213 & 270 & 213 \\
\hline adjusted $R^{2}$ & 0.135 & 0.371 & 0.141 & 0.372 & 0.153 & 0.392 & 0.188 & 0.410 \\
\hline
\end{tabular}


Table 4

The endogeneity-robust impact of project finance on economic growth

The dependent variable is the growth rate. We report the analysis of the project finance-growth nexus based on panel regressions using three 5-year growth periods from 1991 to 1995, 1996 to 2000 and 2001 to 2005 estimated with 3SLS. All regressions instrument PF and FDI with the real exchange rate and lagged values of PF and FDI. For each independent variable, the first row reports the estimated coefficient and the second row reports the $t$ statistic. ${ }^{* * *}, * *$ and $*$ indicate significance at $1 \%, 5 \%$ and $10 \%$ level respectively. The subscript $\mathrm{D}$ indicates a dummy variable. For the definition of all variables see the appendix.

\begin{tabular}{|c|c|c|c|c|c|c|}
\hline & $\operatorname{Reg} 1$ & $\operatorname{Reg} 2$ & Reg 3 & $\operatorname{Reg} 4$ & $\operatorname{Reg} 5$ & $\operatorname{Reg} 6$ \\
\hline \multirow[t]{2}{*}{ constant } & $0.077 * * *$ & $0.097 * * *$ & 0.046 & $0.078 * * *$ & 0.033 & $0.062 * *$ \\
\hline & 2.940 & 4.300 & 1.600 & 3.230 & 1.371 & 2.434 \\
\hline \multirow[t]{2}{*}{ GDP } & $-0.007 * * *$ & $-0.010 * * *$ & $-0.006 * *$ & $-0.008 * * *$ & $-0.006 * *$ & $-0.009 * * *$ \\
\hline & -3.270 & -4.710 & -2.310 & -3.740 & -2.342 & -3.911 \\
\hline \multirow[t]{2}{*}{$\mathrm{PF}$} & 3.925 & 0.934 & & & & \\
\hline & 0.620 & 0.190 & & & & \\
\hline \multirow[t]{2}{*}{$\mathrm{PF}^{*}$ low income country ${ }_{\mathrm{D}}$} & & & $128.335 * * *$ & $70.452 * * *$ & $67.309 * * *$ & $73.547 * * *$ \\
\hline & & & 4.500 & 3.660 & 3.129 & 3.648 \\
\hline \multirow[t]{2}{*}{$\mathrm{PF}^{*}$ middle income country } & & & -5.473 & -3.838 & -9.083 & -3.883 \\
\hline & & & -0.790 & -0.730 & -0.975 & -0.661 \\
\hline \multirow[t]{2}{*}{$\mathrm{PF}^{*}$ high income country $_{\mathrm{D}}$} & & & 15.812 & 12.607 & 2.200 & -0.885 \\
\hline & & & 0.680 & 0.650 & 0.089 & -0.041 \\
\hline \multirow[t]{2}{*}{ FDI } & & & & & $0.093 * * *$ & $0.072 * * *$ \\
\hline & & & & & 4.050 & 3.921 \\
\hline \multirow{2}{*}{ schooling } & 0.005 & 0.005 & 0.010 & 0.007 & 0.010 & 0.009 \\
\hline & 0.590 & 0.810 & 1.240 & 1.070 & 1.397 & 1.368 \\
\hline \multirow[t]{2}{*}{ population growth } & $-0.753 * * *$ & $-0.748 * * *$ & $-0.621 * *$ & $-0.707 * * *$ & -0.122 & $-0.508 * *$ \\
\hline & -2.910 & -3.400 & -2.310 & -3.130 & -1.202 & -2.154 \\
\hline \multirow[t]{2}{*}{ government consumption } & 0.000 & 0.000 & -0.004 & -0.003 & -0.002 & -0.005 \\
\hline & -0.060 & -0.060 & -0.610 & -0.570 & -0.299 & -0.795 \\
\hline \multirow[t]{2}{*}{$\mathrm{SSA}_{\mathrm{D}}$} & $-0.023 * * *$ & $-0.022 * * *$ & $-0.027 * * *$ & $-0.024 * * *$ & $-0.025 * * *$ & $-0.027 * * *$ \\
\hline & -3.800 & -4.380 & -4.380 & -4.710 & -4.270 & -4.964 \\
\hline \multirow[t]{2}{*}{ law } & & 0.001 & & 0.001 & & 0.001 \\
\hline & & 1.430 & & 1.010 & & 1.115 \\
\hline \multirow[t]{2}{*}{ black market premium } & & 0.006 & & 0.009 & & 0.013 \\
\hline & & 0.570 & & 0.850 & & 1.293 \\
\hline \multirow[t]{2}{*}{ inflation } & & $-0.029 * * *$ & & $-0.024 * * *$ & & $-0.025 * * *$ \\
\hline & & -7.310 & & -6.170 & & -6.404 \\
\hline \multirow[t]{2}{*}{ openness } & & 0.001 & & 0.004 & & -0.004 \\
\hline & & 0.270 & & 1.330 & & -1.101 \\
\hline observations & 270 & 213 & 270 & 213 & 270 & 213 \\
\hline adjusted $\mathrm{R}^{2}$ & 0.292 & 0.586 & 0.306 & 0.582 & 0.334 & 0.524 \\
\hline
\end{tabular}


Table 5

The outlier-robust impact of project finance on economic growth

The dependent variable is the growth rate. We report the analysis of the project finance-growth nexus based on panel regressions using three 5-year growth periods from 1991 to 1995, 1996 to 2000 and 2001 to 2005 estimated with OLS. Observations which fall in the top-5\% quantile with respect to project finance are considered outliers and have been excluded. For each independent variable, the first row reports the estimated coefficient and the second row reports the t-statistic. $* * *, * *$ and $*$ indicate significance at $1 \%, 5 \%$ and $10 \%$ level respectively. The subscript $\mathrm{D}$ indicates a dummy variable. For the definition of all variables see the appendix.

\begin{tabular}{|c|c|c|c|c|c|c|}
\hline & Reg 1 & Reg 2 & Reg 3 & Reg 4 & Reg 5 & Reg 6 \\
\hline \multirow[t]{2}{*}{ constant } & $0.041 * * *$ & $0.089 * * *$ & $0.039 * * *$ & $0.087 * * *$ & $0.038 * * *$ & $0.082 * * *$ \\
\hline & 3.160 & 5.710 & 2.940 & 5.300 & 2.920 & 5.070 \\
\hline \multirow[t]{2}{*}{ GDP } & $-0.004 * *$ & $-0.009 * * *$ & $-0.004 * *$ & $-0.009 * * *$ & $-0.004 * *$ & $-0.009 * * *$ \\
\hline & -2.430 & -4.460 & -2.290 & -4.300 & -2.130 & -4.290 \\
\hline \multirow[t]{2}{*}{$\mathrm{PF}$} & $19.346 * *$ & 9.676 & & & & \\
\hline & 2.580 & 1.420 & & & & \\
\hline \multirow[t]{2}{*}{$P F *$ low income country ${ }_{D}$} & & & $55.111 * * *$ & $39.872 * * *$ & $55.751 * * *$ & $39.457 * * *$ \\
\hline & & & 3.090 & 2.630 & 3.190 & 2.640 \\
\hline \multirow[t]{2}{*}{$\mathrm{PF}^{*}$ middle income country $_{\mathrm{D}}$} & & & 8.560 & 0.665 & 4.750 & -0.591 \\
\hline & & & 0.930 & 0.080 & 0.520 & -0.070 \\
\hline \multirow[t]{2}{*}{$\mathrm{PF}^{*}$ high income country ${ }_{\mathrm{D}}$} & & & 22.601 & 13.673 & 15.835 & 12.195 \\
\hline & & & 1.610 & 0.950 & 1.130 & 0.860 \\
\hline \multirow[t]{2}{*}{ FDI } & & & & & $0.026 * * *$ & $0.023 * *$ \\
\hline & & & & & 3.230 & 2.480 \\
\hline \multirow[t]{2}{*}{ schooling } & $0.011 *$ & 0.004 & $0.011 *$ & 0.005 & 0.008 & 0.005 \\
\hline & 1.840 & 0.660 & 1.890 & 0.860 & 1.390 & 0.810 \\
\hline \multirow[t]{2}{*}{ population growth } & -0.108 & $-0.691 * * *$ & -0.110 & $-0.709 * * *$ & -0.115 & $-0.663 * * *$ \\
\hline & -1.180 & -3.160 & -1.200 & -3.230 & -1.290 & -3.050 \\
\hline \multirow[t]{2}{*}{ government consumption } & 0.003 & 0.000 & 0.003 & -0.001 & 0.002 & -0.001 \\
\hline & 1.150 & -0.070 & 0.980 & -0.380 & 0.950 & -0.270 \\
\hline \multirow[t]{2}{*}{$\mathrm{SSA}_{\mathrm{D}}$} & $-0.019 * * *$ & $-0.022 * * *$ & $-0.020 * * *$ & $-0.024 * * *$ & $-0.021 * * *$ & $-0.024 * * *$ \\
\hline & -4.030 & -4.740 & -4.320 & -5.070 & -4.610 & -5.150 \\
\hline \multirow[t]{2}{*}{ law } & & $0.001 *$ & & 0.001 & & 0.001 \\
\hline & & 1.710 & & 1.480 & & 1.340 \\
\hline \multirow[t]{2}{*}{ black market premium } & & 0.006 & & 0.006 & & 0.008 \\
\hline & & 0.590 & & 0.660 & & 0.830 \\
\hline \multirow[t]{2}{*}{ inflation } & & $-0.025 * * *$ & & $-0.024 * * *$ & & $-0.025 * * *$ \\
\hline & & -6.710 & & -6.480 & & -6.730 \\
\hline \multirow[t]{2}{*}{ openness } & & 0.000 & & 0.002 & & -0.002 \\
\hline & & 0.150 & & 0.500 & & -0.510 \\
\hline observations & 255 & 201 & 255 & 201 & 255 & 201 \\
\hline adjusted $R^{2}$ & 0.134 & 0.353 & 0.147 & 0.366 & 0.178 & 0.383 \\
\hline
\end{tabular}


Table 6

The endogeneity- and outlier-robust impact of project finance on economic growth

The dependent variable is the growth rate. We report the analysis of the project finance-growth nexus based on panel regressions using three 5-year growth periods from 1991 to 1995, 1996 to 2000 and 2001 to 2005 estimated with 3SLS. All regressions instrument PF and FDI with the real exchange rate and lagged values of PF and FDI. Observations which fall in the top-5\% quantile with respect to project finance are considered outliers and have been excluded. For each independent variable, the first row reports the estimated coefficient and the second row reports the t-statistic. ${ }^{* * *}, * *$ and $*$ indicate significance at $1 \%, 5 \%$ and $10 \%$ level respectively. The subscript D indicates a dummy variable. For the definition of all variables see the appendix.

\begin{tabular}{|c|c|c|c|c|c|c|}
\hline & Reg 1 & Reg 2 & Reg 3 & Reg 4 & Reg 5 & Reg 6 \\
\hline \multirow[t]{2}{*}{ constant } & 0.036 & $0.079 * * *$ & 0.029 & $0.077 * * *$ & 0.027 & $0.068 * * *$ \\
\hline & 1.530 & 3.490 & 1.270 & 3.310 & 1.130 & 2.880 \\
\hline \multirow[t]{2}{*}{ GDP } & $-0.006 * * *$ & $-0.009 * * *$ & $-0.005 * *$ & $-0.009 * * *$ & $-0.004 *$ & $-0.009 * * *$ \\
\hline & -2.740 & -4.280 & -2.170 & -4.010 & -1.830 & -4.270 \\
\hline \multirow[t]{2}{*}{$\mathrm{PF}$} & $84.732 * * *$ & $33.175 * * *$ & & & & \\
\hline & 4.290 & 3.190 & & & & \\
\hline \multirow[t]{2}{*}{$\mathrm{PF}^{*}$ low income country ${ }_{\mathrm{D}}$} & & & $111.112 * * *$ & $51.841 * * *$ & $104.217 * * *$ & $45.633 * * *$ \\
\hline & & & 3.840 & 3.240 & 3.430 & 2.870 \\
\hline \multirow[t]{2}{*}{$\mathrm{PF}^{*}$ middle income country $_{\mathrm{D}}$} & & & 35.559 & 18.124 & 25.789 & 9.176 \\
\hline & & & 1.520 & 1.340 & 0.990 & 0.680 \\
\hline \multirow[t]{2}{*}{$\mathrm{PF}^{*}$ high income country $_{\mathrm{D}}$} & & & $58.034 * * *$ & 22.190 & 22.811 & 11.366 \\
\hline & & & 2.690 & 1.220 & 0.970 & 0.590 \\
\hline \multirow[t]{2}{*}{ FDI } & & & & & $0.072 * * *$ & $0.050 * * *$ \\
\hline & & & & & 3.350 & 3.170 \\
\hline \multirow[t]{2}{*}{ schooling } & $0.014 * *$ & 0.005 & $0.012 *$ & 0.006 & 0.008 & 0.007 \\
\hline & 2.010 & 0.760 & 1.840 & 0.950 & 1.050 & 1.180 \\
\hline \multirow[t]{2}{*}{ population growth } & -0.066 & $-0.737 * * *$ & -0.111 & $-0.749 * * *$ & -0.116 & $-0.611 * * *$ \\
\hline & -0.650 & -3.350 & -1.160 & -3.350 & -1.190 & -2.730 \\
\hline \multirow[t]{2}{*}{ government consumption } & 0.000 & -0.004 & -0.001 & -0.004 & -0.002 & -0.004 \\
\hline & 0.060 & -0.670 & -0.210 & -0.710 & -0.280 & -0.740 \\
\hline \multirow[t]{2}{*}{$\mathrm{SSA}_{\mathrm{D}}$} & $-0.015 * * *$ & $-0.019 * * *$ & $-0.018 * * *$ & $-0.021 * * *$ & $-0.022 * * *$ & $-0.023 * * *$ \\
\hline & -2.630 & -3.850 & -3.160 & -4.200 & -3.590 & -4.480 \\
\hline \multirow[t]{2}{*}{ law } & & 0.001 & & 0.001 & & 0.001 \\
\hline & & 1.400 & & 1.170 & & 1.280 \\
\hline \multirow[t]{2}{*}{ black market premium } & & 0.008 & & 0.008 & & 0.012 \\
\hline & & 0.820 & & 0.870 & & 1.260 \\
\hline \multirow[t]{2}{*}{ inflation } & & $-0.026 * * *$ & & $-0.025 * * *$ & & $-0.026 * * *$ \\
\hline & & -6.750 & & -6.590 & & -7.020 \\
\hline \multirow[t]{2}{*}{ openness } & & 0.001 & & 0.002 & & -0.005 \\
\hline & & 0.350 & & 0.660 & & -1.350 \\
\hline observations & 255 & 201 & 255 & 201 & 255 & 201 \\
\hline adjusted $R^{2}$ & 0.253 & 0.446 & 0.284 & 0.467 & 0.337 & 0.501 \\
\hline
\end{tabular}

